\title{
THE EFFECT OF HABITAT AND SEDIMENT TYPE ON THE OCCURRENCE OF NON-NATIVE AND NATIVE SPECIES OF AQUATIC MACROPHYTE IN SUBTROPICAL REGIONS
}

\author{
EFEITO DO HABITAT E DO TIPO DE SEDIMENTO NA OCORRENCIA DE UMA \\ ESPÉCIE NÃO-NATIVA E UMA ESPÉCIE NATIVA DE MACRÓFITA AQUÁTICA NA \\ REGIÃO SUBTROPICAL
}

\author{
Márcio José SILVEIRA ${ }^{1}$ \\ 1. State University of Maringá - UEM Research group in Limnology, Ictiology and Aquaculture - Nupelia Laboratory of Limnology \\ and Aquatic Macrophytes; s.marciojs@gmail.com
}

\begin{abstract}
Non-native species of aquatic plants may become invasive and affect native communities, reducing the diversity of plants and other organisms. In general, the successful colonization of new habitats by macrophytes depends first on their dispersion ability and second on the existence of favorable abiotic conditions. In this investigation, we used a transplant experiment to test the effects of habitat water (main river channel versus lake) and habitat sediment (river sediment versus lake sediment) on the growth of two species, the non-native Hydrilla verticillata and the native macrophyte Egeria najas. We tested the hypothesis that the non-native species is more successful when it grows in the river channel with river sediment as substrate, whereas the native E. najas is more successful when it grows in the lake with lake sediment as substrate. Fragments of both species were planted in river and lake sediment and transported to the main river channel and a lake for the growing period. The field experiment results demonstrated that $H$. verticillata did not grow in either river or lake sediment when planted in the lake. However, this species developed higher root biomass than E. najas in the main river channel, which explains its predominance in this type of habitat. The results support the view that habitat characteristics are determinants of the successful or unsuccessful growth of $H$. verticillata in our study sites. Finally, $H$. verticillata invasiveness may improve after certain lag times in response to alterations in habitat, as observed for several other non-native species. Thus, future invasions of floodplain lakes by this species cannot be discarded.
\end{abstract}

KEYWORDS: Floodplain. Experimental. Hydrilla verticillata. Egeria najas.

\section{INTRODUCTION}

Non-native invasive species have attracted considerable attention due to their potential impacts on natural ecosystems (MACK et al., 2000) and their relevance for testing ecological theories (TILMAN, 1997; SAX et al., 2007).

In general, the successful colonization of new habitats by organisms (including macrophytes) depends primarily on the dispersion ability of species (SAX et al., 2007; VAN DER VALK et al., 2009). For some species of macrophytes, such as those belonging to the family Hydrocharitaceae, vegetative propagules are an important strategy for dispersion and colonization of novel sites (SCULTHORPE, 1967). Abiotic filters (e.g., transparency of water, nutrients of water and sediment, organic matter of sediment) are also important determinants of native and non-native species success; for example, the existence of favorable environmental conditions related to nutrients, underwater light and sediment properties can determine the success or failure of macrophytes in various environments (VAN DEN BERG et al., 2003; SOUSA et al., 2009).
The species Hydrilla verticillata (L.f.) Royle (hereafter Hydrilla) is native to Asia and Australia (COOK; LUOND, 1982). In Brazil, this species is found in reservoirs (THOMAZ et al., 2009) and recently invaded the Upper Parana River (SOUSA et al., 2009), a strategic ecosystem for biodiversity conservation in Brazil. Since then, it has rapidly spread along the Upper Parana River, infesting large areas with high biomass production and causing problems related to navigation, fishing and recreation activities. Although Hydrilla demonstrates a high amplitude of occurrence in several environmental conditions (SOUSA, 2011), in Brazil it succeeds only in the main river and lateral channels and has rarely been recorded in lakes (SOUSA et al., 2009). However, Egeria najas Planch. (hereafter Egeria), the dominant native submerged macrophyte in the Upper Parana River, is found predominantly in lakes and exhibits low occurrence in the main river channel (SOUSA et al., 2009). Although the species above (both belonging to the family Hydrocharitaceae) occur predominantly in different locations, these two species 
have similar morphological characteristics (BECKER et al., 2007).

The different distribution of these two species of macrophytes may be associated with abiotic conditions (transparency of water and type of sediment), which differ between main river channels and lakes. For example, the main river channel and its lateral channels have a higher current flow and a lower concentration of organic matter in sediment lakes than floodplain lakes (SOUSA et al., 2009). In addition to the potential limitations caused by abiotic factors, dispersion may also explain the different patterns of distribution in the Upper Parana habitats.

Thus, the purpose of this paper was to investigate which factor can be responsible for the colonization of Hydrilla verticillata in different habitats of subtropical regions. In this investigation, we used a transplant experiment to test the effects of habitat water (main river channel versus lake) and habitat sediment (river sediment versus lake sediment) on the growth of Hydrilla and the native macrophyte Egeria. We predicted that Hydrilla would be more successful when grown in the river channel with river sediment as substrate, whereas the native Egeria would be more successful when grown in the lake with lake sediment as substrate. This prediction was based on several papers that demonstrated that Hydrilla does not grow in sites with high concentrations of organic matter in the sediment (BARKO et al., 1986; SOUSA et al., 2009).

\section{MATERIAL AND METHODS}

The experiment was conducted in situ in November 2009 during the period of low waters in two habitats: one in the main river channel (S $22^{\circ} 45^{\prime} .887^{\prime}$ " latitude and $\mathrm{W} 053^{\circ} 15^{\prime} .462^{\prime}$ " longitude) and the second in a lake ("Leopoldo") connected to the river (S 22 43'23.7' latitude and $\mathrm{W}$ 053 16'08.6' longitude), both in the Upper Paraná River.

Both habitats demonstrated differences in the sediment characteristics; the river had a more sandy sediment, and the lake had a more muddy sediment (SOUSA et al., 2009).

Apical fragments $(10 \mathrm{~cm})$ of the two species (Hydrilla and Egeria) were planted separately in 0.5 $\mathrm{L}$ plastic cups in both river and lake sediments. For each habitat (river and lake), we transplanted 10 fragments of each species; five fragments were planted in river sediment, and 5 fragments were planted in lake sediment. Each species had five replicates of each treatment combination (sediment and habitat). In total, 40 cups were used in the experiment.

The cups containing the plants with the different sediment type were located outside the existing stands of macrophytes in the main river channel and lake to minimize the influence of these stands on plant growth. Then the cups remained in place for 30 days at a depth of ca. $1 \mathrm{~m}$.

\section{Water and sediment features}

We measured the following water abiotic parameters at the beginning and end of the experiment: temperature, oxygen, $\mathrm{pH}$, conductivity, alkalinity and underwater radiation (PAR). The underwater radiation was measured at $0.2 \mathrm{~m}$ and 0.6 $\mathrm{m}$, and the coefficient of light attenuation $(k)$ was estimated as $\left[\log \left(I_{0}\right)-\log \left(I_{z}\right)\right] / z$, where $I_{0}$ and $I_{z}$ are the radiation measurements at $0.2 \mathrm{~m}$ and $0.6 \mathrm{~m}$, respectively, and $z$ is the difference in depth (0.4). The Kjeldahl nitrogen (N) (MACKERETH et al., 1978) and total phosphorus (P) (GOLTERMAN et al., 1978) in the water were also measured.

At the end of the experiment, we also measured the nutrient concentrations of $\mathrm{N}, \mathrm{P}$ and organic matter in the sediment of all cups. The available $\mathrm{N}$ and $\mathrm{P}$ were extracted with solutions of $\mathrm{KCl}$ (1 hour) and $\mathrm{NaOH}-\mathrm{NaCl}$ (16 hours), and the concentrations were determined in a spectrophotometer as $\mathrm{NH}_{4}{ }^{+}$e $\mathrm{PO}_{4}{ }^{3-}$, following the methodology of BREMNER (1965), and expressed as $\mu \mathrm{g} \mathrm{gDW}^{-1}$. The organic matter content of the sediment was calculated after drying ca. $1.0 \mathrm{~g}$ in an oven at $550{ }^{\circ} \mathrm{C}$ for 4 hours and is expressed as $\%$ OMsed $\mathrm{g} \mathrm{DW}^{-1}$ (SOUSA et al., 2009).

In addition, at the end of the experiment (time; 30 days), the cups were removed and the following attributes were measured for each plant: plant dry weight, (stems, branches, roots), root dry weight, number of lateral branches and plant length (cm). Dry weight (DW) was obtained after drying at ca. $80{ }^{\circ} \mathrm{C}$ until a constant weight was reached and is expressed as $\mathrm{g} / \mathrm{DW}^{-1}$.

\section{Statistical Analyses}

Hydrilla did not grow in the lake (all values zero; Figures 1 and 2); the lake was therefore not considered a habitat type (main river channel versus lake) for analyses with this species. We applied twoway ANOVA to assess differences between species and sediment (river sediment and lake sediment) for all attributes where both species increased in the main river channel.

For Egeria, which grew in both the river and lake environments, we also applied two-way 
ANOVA to analyze differences between habitat and sediment types.

We also applied one-way ANOVA to assess differences between river and lake $\mathrm{N}, \mathrm{P}$ and $\mathrm{OM}$ in sediment. The normality of the data was tested using a Shapiro-Wilk test and homoscedasticity was tested using a Levene test.

\section{RESULTS}

The main river channel water had higher values of $k$ and lower values of water $\mathrm{N}$ and $\mathrm{P}$ than the lake water, but all other parameters were similar between both habitats (Table 1). The assumptions of normality and homoscedasticity were met for all attributes measured in both species. The results also demonstrated that the river sediment had significantly lower N, P and OM concentrations than the lake sediment (Table 2).

Table 1. Mean $( \pm \mathrm{SD})$ of the abiotic parameters registered during the in situ study in both environments at the beginning and end of the experiment.

\begin{tabular}{lcc}
\hline Abiotic parameters & $\begin{array}{c}\text { Main River } \\
\text { Channel }\end{array}$ & Lake \\
\hline Temperature $\left({ }^{\circ} \mathrm{C}\right)$ & $30.3 \pm 0.8$ & $29.7 \pm 0.6$ \\
OD $(\mathrm{mg} / \mathrm{l})$ & $7.37 \pm 0.07$ & $6.61 \pm 0.28$ \\
$\mathrm{OD}(\%)$ & $88.3 \pm 0.21$ & $83.4 \pm 0.70$ \\
$\mathrm{pH}$ & $7.15 \pm 0.07$ & $6.83 \pm 0.02$ \\
Conductivity $\left(\mu \mathrm{S} \mathrm{cm}^{-1}\right)$ & $64 \pm 0.1$ & $70 \pm 0.1$ \\
Alkalinity $\left(\mu \mathrm{Eq} \mathrm{l}^{-1}\right)$ & $362 \pm 12$ & $385 \pm 14$ \\
$\mathrm{k}\left(\mathrm{m}^{-1}\right)$ & $0.96 \pm 0.06$ & $0.41 \pm 0.002$ \\
Kjeldahl N $\left(\mu \mathrm{g} \mathrm{l}^{-1}\right)$ & $993 \pm 108$ & $1390 \pm 432$ \\
Total P $\left(\mu \mathrm{g} \mathrm{l^{-1 }}\right)$ & $14 \pm 0.7$ & $81 \pm 2$ \\
\hline
\end{tabular}

Table 2. Mean $( \pm \mathrm{SD})$ of available N, $\mathrm{P}$ and organic matter measured in river sediment and lake sediment. The results of the one-way ANOVA are also shown.

\begin{tabular}{lcccc}
\hline Abiotic parameters & $\begin{array}{c}\text { River } \\
\text { sediment }\end{array}$ & $\begin{array}{c}\text { Lake } \\
\text { sediment }\end{array}$ & $\mathrm{F}$ & $p$ \\
\hline $\mathrm{N}\left(\mu \mathrm{gDW}^{-1}\right)$ & $4.9 \pm 0.57$ & $16.6 \pm 2.58$ & 327.18 & $<\mathbf{0 . 0 5}$ \\
$\mathrm{P}\left(\mu \mathrm{gDW}^{-1}\right)$ & $7.9 \pm 0.09$ & $14.2 \pm 3.5$ & 61.25 & $<\mathbf{0 . 0 1}$ \\
$\mathrm{OM}\left(\% \mathrm{gDW}^{-1}\right)$ & $0.17 \pm 0.07$ & $14.9 \pm 3.26$ & 469.03 & $<\mathbf{0 . 0 5}$ \\
\hline
\end{tabular}

The Egeria individuals grew in the river and lake independent of the type of sediment (Figures 1 and 2). However, Hydrilla individuals grew in the experiment with both sediment types only in the river; none of the individuals grew in the lake, regardless of the type of sediment, and thus, all attributes (plant DW and root DW, number of lateral branches and plant length) for this treatment were zero (Figures 1 and 2).

The results demonstrated that for the biomass (plant DW) of Egeria, the effects of sediment, habitat and the sediment and habitat interaction were not significant.

The effects of river and lake sediment and habitat on root DW were significant, and an interaction was found between these two factors $\left(\mathrm{F}_{1,16}=14.20 ; \mathrm{p}<0.001\right)$. Egeria had a higher root DW when growing in lake sediment in the river
(Figure 1b), but the effects of sediment and habitat when analyzed individually were not significant.

As shown in Figure 2a, the results demonstrate that the number of lateral branches were not significant when this attribute was analyzed separately for the treatments of sediment and habitat, but the sediment $\mathrm{x}$ habitat interaction was significant $\left(\mathrm{F}_{1,16}=37.03 ; \mathrm{p}<0.001\right)$. Egeria growing in the main river channel had more branches than those growing in the lake.

Plant length differed between habitat $\left(\mathrm{F}_{1,16}=4.86 ; \mathrm{p}<0.05\right)$, and the sediment $\mathrm{x}$ habitat interaction was also significant $\left(\mathrm{F}_{1,16}=12.23\right.$; $\mathrm{p}<0.005)$; however, this interaction was not significant for sediment. In both sediment types, Egeria reached a greater length in the lake compared with the river (Figure 2b). 

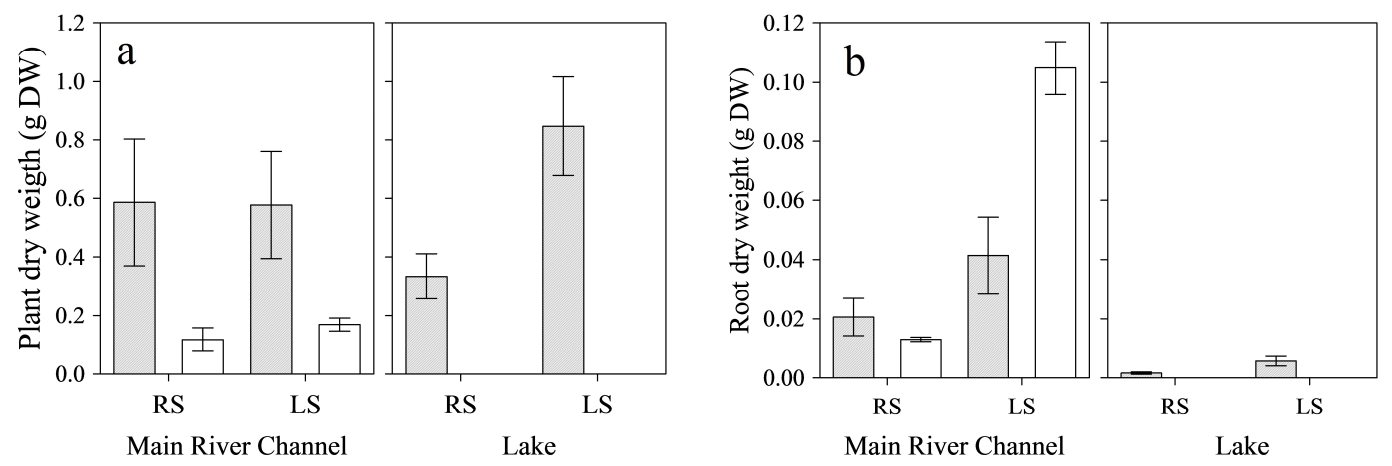

Figure 1. Mean values $( \pm \mathrm{SD})$ of total plant dry weight (a) and root dry weight (b) obtained in the river sediment (RS) and in the lake sediment (LS) for plants growing in the main river channel and in the lake. Egeria: grey bars; Hydrilla: empty bars. Note that Hydrilla did not grow in either type of sediment in the lake.
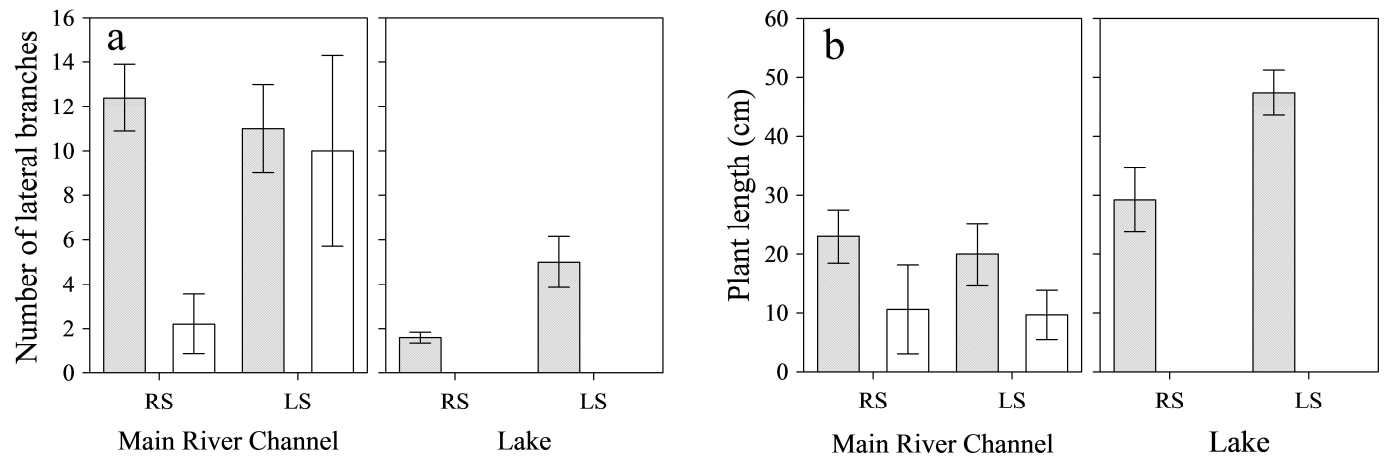

Figure 2. Mean values $( \pm \mathrm{SD})$ of the number of branches (a) and plant length (b) obtained in the river sediment (RS) and in the lake sediment (LS) for plants growing in the main river channel and in the lake. Egeria: grey bars; Hydrilla: empty bars. Note that Hydrilla did not grow in either type of sediment in the lake.

When Egeria and Hydrilla were analyzed in the different sediment (river sediment and lake sediment) types in the river, the plant length and plant DW were not significantly different. However, root DW and the number of lateral branches demonstrated significantly different values for sediment $\left(F_{1,16}=18.68 ; p<0.001\right.$ and $F=5.30 ; p<0.05$, respectively); for both attributes, root $\mathrm{DW}$ and the number of lateral branches also demonstrated interactions between sediment $x$ species $\left(\mathrm{F}_{1,16}=7.85\right.$; $\mathrm{p}<0.01$ and $\mathrm{F}_{1,16}=8.78 ; \mathrm{p}<0.01$, respectively). Egeria had a lower root DW than Hydrilla in both sediment types, but the difference was greater in lake sediment (Figure 1b); by contrast, in both sediment types, Egeria had a higher number of branches compared with Hydrilla (Figure 2a).

\section{DISCUSSION}

The results indicate that Egeria performs better than Hydrilla in lentic, shallow and turbid habitats, thus corroborating our hypothesis. These experimental findings are consistent with observational studies conducted in the Paraná River and its floodplain, which have found Egeria in main river channel but its success of colonization is mainly in lakes, whereas Hydrilla almost exclusively colonizes the river channel (SOUSA et al., 2009). However, although Hydrilla fragments are found in the lakes (SOUSA et al. 2009), our experiment strongly supports the idea that they are not adapted to grow in this type of habitat.

The results support the view that both lake water and sediment possibly determine the unsuccessful colonization of the Paraná floodplain lakes by Hydrilla. Although it is difficult to determine the main factors that influence the differential response of these two species in lake and river habitats, lower light availability and high sediment organic matter in the lake may help to explain our findings. In fact, the optimum light requirement for Hydrilla varies from 500-700 $\mu \mathrm{M}$ 
$\mathrm{m}^{-2} \mathrm{~s}^{-1}$ (SOUSA, 2011), whereas it is $80-100 \mu \mathrm{M} \mathrm{m}^{-}$ $2 / \mathrm{s}^{-1}$ for Egeria (TAVECHIO; THOMAZ, 2002). These results indicate that Egeria is more adapted to light limitations (typical of lake habitats) than the former. Regarding sediment, a high organic matter content (typical of lake sediment) is considered limiting for Hydrilla growth because toxic gases such as $\mathrm{H}_{2} \mathrm{~S}$ (to which Hydrilla is highly sensitive) may be produced in sediments under these conditions (WANG et al., 2007; SOUSA et al., 2009).

Although this explanation has received experimental confirmation (WANG et al., 2007), it leads to an apparent contradiction because Hydrilla grew in cups containing lake sediment in the river habitat but did not grow in cups containing river sediment in the lake habitat (see Figures 1 and 2). However, this finding can be explained by the fact that the well-oxygenated water in the river reduces anoxic conditions in sediment and contributes to the exchange of gases between the water and the leaves, alleviating the noxious effects observed in lake sediments. In addition, water characteristics (e.g., turbidity) may also be the main factor affecting its unsuccessful colonization in lakes because Hydrilla did not grow in river sediment in the lake.

According to long-term data obtained from the Paraná River and its floodplain, lakes that are connected to the main river channel differ from the latter mainly by having higher turbidity and sediment organic matter (ROBERTO et al., 2009; SOUSA et al., 2009). The physicochemical data confirmed these differences, which may be one of the reasons for the predominance of Hydrilla in the main river channel and its unsuccessful colonization of lakes.

Because Hydrilla did not grow in the lake, the strategies employed in different habitats can only be analyzed for Egeria. An interesting finding was that this species grew in the cups maintained in the river, demonstrating that this habitat is also suitable for its development, in addition to lakes, as demonstrated by SOUSA et al., 2009. This species also developed more lateral branches in the river than in the lake (see Figure 2a). The velocity of water can be considered a stress for submerged plants, and strategies to reduce the specific leaf area may be a response of this species in sites with high velocities of water (BOEGER; POULSON, 2003; SCULTHORPE, 1967).

The difference between habitats regarding Egeria root development, which was higher in the river compared with the lake, was possibly due to the need to anchor the plant against the current velocity in the river, but this result could also be a response to the low nutrient availability in this river. In fact, root:branches ratios usually increase when nutrients limit macrophyte growth (e.g., MONY et al., 2007; HUSSNER, 2009). In addition, although submerged plants absorb nutrients predominantly from their roots, they can also absorb nutrients from leaves in more eutrophic conditions (CARIGNAN; KALFF, 1980). Thus, nutrients can be supplied more through these organs in the lake (richer in nutrients), and as a consequence, the plants direct less biomass to the roots in this habitat. Investment in shoot elongation in the lake (see Figure 2b) as a response to low light availability may also explain the lower root development in this habitat.

In summary, the results indicated that habitat characteristics may be the determinant of the unsuccessful colonization of lakes by Hydrilla in the Upper Paraná floodplain. In addition, the rapid growth of Egeria in the lake observed in this study, together with the formation of a canopy, may provide some advantage to this species and may partially explain why Hydrilla has not been found in the Upper Paraná River lakes. However, other factors not addressed in this experiment, such as the rapid regeneration of Hydrilla from tubers and the influence of water velocity, might be important to explain the success of Hydrilla in the main channel of the Paraná River. Finally, Hydrilla invasiveness may improve after a certain time lag in response to alterations in habitat, as observed for several other non-native species (e.g., SIMBERLOFF, 2009). Thus, the invasion of floodplain lakes by this species cannot be discarded. Future studies on Hydrilla and native species in which these additional factors are considered may contribute to understanding their distribution in the Paraná River basin and to predicting which sites are the most prone to invasion.

\section{ACKNOWLEDGMENTS}

Acknowledges the "Parque Tecnológico da Itaipu" (PDTA/FPTI-BR), for providing a MSc. scholarships and to the CNPq " Conselho Nacional de Desenvolvimento Ciêntífico e Tcnológico Brasil" by grants. I thank Msc. Roberta Becker Rodrigues for helping with the laboratory analysis. 
RESUMO: Espécies não-nativas de plantas aquáticas podem se tornar invasoras e afetar as comunidades nativas, reduzindo a diversidade de plantas e de outros organismos. Em geral, a colonização por macrófitas em novos habitats depende em primeiro lugar de sua capacidade de dispersão e à existência de condições abióticas favoráveis. Nesta investigação foi utilizado um experimento de transplante para testar os efeitos da água do habitat (calha principal do rio versus lago) e sedimentos do habitat (sedimento do rio versus sedimento do lago) sobre o crescimento de duas espécies de macrófitas aquáticas a não-nativa Hydrilla verticillata e nativa Egeria najas. Foi testada a hipótese de que as espécie nãonativa é mais bem sucedida quando cresce no canal do rio com sedimento do rio como substrato, enquanto a nativa $E$. najas é mais bem sucedida quando cresce no lago com sedimento do lago como substrato. Fragmentos de ambas as espécies foram plantadas em sedimentos do rio e do lago e transportadas para o Rio e um lago para o cultivo. Resultados em campo mostraram que $H$. verticillata não cresceu no lago, em ambos os sedimentos (rio e lago). No entanto, esta espécie desenvolveu maior biomassa da raiz no rio, comparada a E. najas, o que explica sua predominância neste tipo de habitat. Os resultados apóiam a visão de que as características do habitat são determinantes para o sucesso ou insucesso de $H$. verticillata nos locais em que foram estudados. Finalmente, a invasão $H$. verticillata pode melhorar após um determinado intervalo de tempo em resposta a alterações no habitat, como observado para várias outras espécies nãonativas e, portanto, a futura invasão de lagos de várzea por esta espécie não pode ser descartada.

PALAVRAS-CHAVE: Planície de inundação. Experimento de transplante. Hydrilla verticillata, Egeria najas

\section{REFERENCES}

BARKO, J. W.; SMART, R. M. Sediment-related mechanisms of growth limitation in submersed macrophytes. Ecology. Washington, DC, v. 65, n. 5, p. 1328-1340, Oct. 1986.

BREMMER, J. M. 1965. Inorganic forms of nitrogen. In: Black, C.A. (Eds.), Methods of soil analysis Wisconsin, American Society of Agronomy, USA, pp. 1179-1237.

BOEGER, M. R. T.; POULSON, M. E. Morphological adaptations and photosynthetic rates of amphibious Veronica anagallis-aquatica L. (Scrophulariaceae) under different flow regimes. Aquatic Botany. Amsterdam, v. 75, n. 1, p. 123-135, Jan. 2003. http://dx.doi.org/10.1016/S0304-3770(02)00174-2

CARIGNAN, R.; KALFF, J. Phosphorus sources for aquatic weeds water or sediments. Science. England, v. 207, n. 4434, 987-989, Feb. 1980.

COOK, C. D. K.; Luond, R. A revision of the genus Hydrilla (Hydrocharitaceae). Aquatic Botany. Amsterdam, v. 13, n. 1, p. 485-504, 1982. http://dx.doi.org/10.1016/0304-3770(82)90074-2

GOLTERMAN, H. L.; CLYMO, R. S.; OHMSTAD, M. A. M. Methods for physical and chemical analysis of freshwaters. - Blackwell Scientific publication. Oxford, 1978, 213pp.

HUSSER, A. Growth and photosynthesis of four invasive aquatic plant species in Europe. Weed Research. Netherlands, v. 49, n. 5, p. 506-515, Sep. 2009. http://dx.doi.org/10.1111/j.1365-3180.2009.00721.x

MACK, R. N.; SIMBERLOFF, D.; LONSDALE, W. M.; EVANS, H.; CLOUT, M.; BAZZAZ, F. A. Biotic invasions: Causes, epidemiology, global consequences, and control. Ecological Society of America. USA, v. 10, n. 3, p. 689-710, Nov. 2000.

MACKERETH, F. I. F.; HERON J.; TALLING, J. F. Water Analysis: some revised methods for limnologist. Freshwater Biological Association Scientific Publication, England, v. 64, n. 4, p. 456, 1978.

MONY, C.; KOSCHNICK, T. J.; HALLER W. T.; MULLER, S. Competition between two invasive Hydrocharitaceae (Hydrilla verticillata (L. f.) (Royle) and Egeria densa (Planch) as influenced by sediment fertility and season. Aquatic Botany, Amsterdam, v. 86, n. 5 p. 236-242, Oct. 2007. http://dx.doi.org/10.1016/j.aquabot.2006.11.007 
ROBERTO, M. C.; SANTANA, N. F.; THOMAZ, S. M. Limnology in the Upper Paraná River floodplaIn large-scale spatial and temporal patterns, and the influence of reservoirs. Brazilian Journal of Biology, Brazil, v. 69 , n. 2, p. 717-725, May. 2009.

SAX, D. F.; STACHOWIEZ, J. J.; BROWN, J.H.; BRUNO, J. F.; DAWSON, M.N.; GAINES, S. D.; GROSBERG, R. K.; HASTING, A.; HOLT, R. D.; MAYFIELD, M. M.; O’CONNOR, M. I.; RICE, W. R. Ecological and evolutionary insights from species invasions. Trends in Ecology and Evolution, England, v. 22, n. 9, p. 465-471, Jun. 2007. http://dx.doi.org/10.1016/j.tree.2007.06.009

SCULTHORPE, David. The Biology of Aquatic Vascular Plants. - Edward Arnold Publishers, London, 1967.

SIMBERLOFF, D. The Role of Propagule Pressure in Biological Invasions. Annual Review of Ecology, Evolution and Systematics, USA, v. 40, p. 81-102, Aug. 2009. http://dx.doi.org/10.1146/annurev.ecolsys.110308.120304

SOUSA, W. T. Z.; THOMAZ, S. M.; MURPHY, K. J.; SILVEIRA, M. J.; MORMUL, R. P. Environmental predictors of exotic Hydrilla verticillata (L.f.) Royle and a native Egeria najas Planch. occurrence in a subtropical river floodplain: the upper River Paraná, Brazil. Hydrobiologia, Netherlands, v. 632, n. 1, p. 65-78, Aug. 2009. http://dx.doi.org/10.1007/s10750-009-9828-3

SOUSA, W. T. Z.; THOMAZ, S. M.; MURPHY, K. Drivers of aquatic macrophyte community structure in a Neotropical riverine lake. Acta Oecologica, France, v. 37, n. 5, p. 462-475, Sept-Oct. 2011. http://dx.doi.org/10.1016/j.actao.2011.05.015

TAVECHIO, W. L. G.; THOMAZ, S. M. Effects of Light on the Growth and Photosynthesis of Egeria najas Planchon. Brazilian Archives of Biology and Technology, Brazil, v. 43, n. 2, p. 206-209, Mar. 2002.

TILMAN, D. Community invasibility, recruitment limitation, and grassland biodiversity. Ecology, USA, v. 78, n. 1, p. 81-92, Mar. 1997. http://dx.doi.org/10.1890/0012-9658(1997)078[0081:CIRLAG]2.0.CO;2

THOMAZ, S. M.; CARVALHO, P., MORMUL, R. P.; FERREIRA, F. A.; SILVEIRA, M. J.; MICHELAN, T. S. Temporal trends and effects of diversity on occurrence of exotic macrophytes in a large reservoir. Acta Oecologica. France, v. 35, n. 2 p. 614-620, 2009. http://dx.doi.org/10.1016/j.actao.2009.05.008

VAN DEN BERG, M. S.; JOOSSE, W.; COOPS, H. A statistical model predicting the occurrence and dynamics of submerged macrophytes in shallow lakes in the Netherlands. Hydrobiologia, Netherlands, 506, n. 1-3, p. 611-623, Nov. 2003.

VAND DER VALK, A. G.; TOTH, L. A.; GIBNEY, E. B.; MASON, D. H.; WETZEL, P. R. Potencial propagule sources for reestablishing vegetation on the floodplain of the Kissimmee River, Florida, USA. Wetlands, USA, v. 29, n. 3, p. 976-987, Sept. 2009. http://dx.doi.org/10.1007/BF03173624

WANG, S. R.; JIN, X. C.; ZHAO, H. C.; ZHOU, X. N.; WU, F. C. Effects of Hydrilla verticillata on phosphorus retention and release in sediments. Water Air Soil Pollution, Netherlands, v. 181, n. 1-4, p. 329339, May. 2007. 